\title{
Trends in fishery-dependent captures of sea turtles in a western North Atlantic foraging region
}

\author{
Joanne Braun McNeill ${ }^{1, *}$, April Goodman Hall ${ }^{1}$, Paul M. Richards ${ }^{2}$
}

${ }^{1}$ NOAA, National Marine Fisheries Service, Southeast Fisheries Science Center, 101 Pivers Island Road, Beaufort, NC 28516, USA

${ }^{2}$ NOAA, National Marine Fisheries Service, Southeast Fisheries Science Center, 75 Virginia Beach Drive, Miami, FL 33149, USA

\begin{abstract}
Accurate assessments of sea turtle populations are essential for determining population trends and formulating conservation plans for the recovery of these imperiled species. Although counting nesting females and nests has been widely used to assess abundance, surveys of in-water populations can provide a more effective means of measuring the success of recovery actions. An in-water survey within the Pamlico-Albemarle Estuarine Complex of North Carolina, USA, was begun in 1995 to monitor trends in sea turtle populations, and 3 sampling periods were established: 1995-1997, 2001-2003, and 2007-2009. A significant increase in loggerhead Caretta caretta captures was detected among the 3 sampling periods, while the addition of sampling in 2007-2009 ( $\mathrm{n}=887$ unique individuals) revealed significant increases in capture rates of green Chelonia mydas and Kemp's ridley Lepidochelys kempii sea turtles. Species composition also changed from a dominance of loggerheads in the early sampling periods to an equivalent proportion of green and loggerhead sea turtles in 2007-2009; North Carolina stranding data displayed similar changes in species composition during 2007-2009. Though logistically difficult, long-term in-water studies are critical for monitoring trends in sea turtle populations and implementing effective conservation plans.
\end{abstract}

KEY WORDS: Sea turtles · Population assessments - In-water surveys · Capture rates · Trends · Loggerhead $\cdot$ Green $\cdot$ Kemp's ridley

\section{INTRODUCTION}

Long lifespans, late age at sexual maturity, and complex life histories make acquiring data for accurate assessments of sea turtle populations difficult (National Research Council 2010). Nevertheless, reliable data for determining population trends and formulating conservation plans are essential for the recovery of these imperiled species (Bjorndal et al. 2005). Traditionally, monitoring nesting beaches has been the most widely used method for assessing and monitoring the status of sea turtle populations (Meylan 1995, Schroeder \& Murphy 1999, Broderick et al. 2006, Pfaller et al. 2013). However, since sea turtles do not breed every year, the resulting interannual variation in number of nesting females may

${ }^{*}$ Corresponding author: joanne.b.mcneill@noaa.gov conceal changes in population size (Broderick et al. 2001). Additionally, the non-breeding female, male, and juvenile components of the population are not evaluated during nesting surveys (Chaloupka \& Limpus 2001), and all life stages of a population should be measured to accurately evaluate population trends (Butler et al. 1987). Conversely, surveys at earlier life stages (juvenile and subadult) provide a more timely and accurate method of measuring the effectiveness of recovery actions (Butler et al. 1987, Bjorndal et al. 2005, National Research Council 2010). Therefore, despite the costs and difficult logistics, critical inwater sampling of sea turtle populations should augment nesting surveys (Chaloupka \& Limpus 2001) to understand current, and predict future, trends in sea turtle populations (National Research Council 2010).

(C) Outside the USA, the US Government 2018. Open Access under Creative Commons by Attribution Licence. Use, distribution and reproduction are unrestricted. Authors and original publication must be credited.

Publisher: Inter-Research · www.int-res.com 
The largest estuarine system in the southeastern USA, the Pamlico-Albemarle Estuarine Complex (PAE Complex), comprises several coastal lagoons separated from the ocean by barrier islands and provides important habitat for many juvenile marine species (see Epperly et al. 2007 for a detailed description). These estuarine waters serve as important foraging and developmental habitat for benthic immature loggerhead Caretta caretta, green Chelonia mydas, and Kemp's ridley Lepidochelys kempii sea turtles (Epperly et al. 1995). Sea turtles are present in these inshore waters from April to December and are frequently captured in pound nets set behind the barrier islands (Epperly et al. 1995). Pound nets are a passive, stationary fishing gear (Higgins \& Pearson 1928). During autumn and early winter (September-December), when pound nets

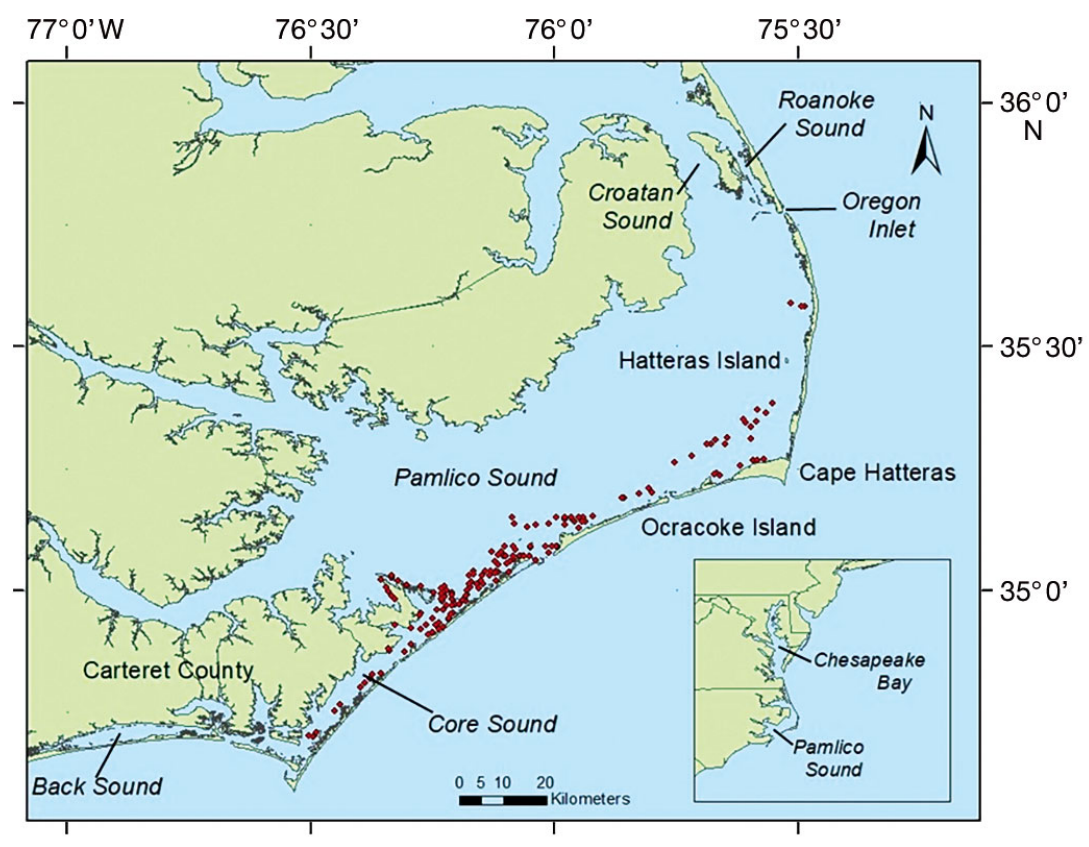

Fig. 1. Pamlico-Albemarle Estuarine Complex, NC, USA, showing the locations of sets sampled 1995-2009. Albemarle and Currituck sounds are to the north and are not shown are set to capture flounder, many intercept sea turtles leaving the sounds (Epperly et al. 2007). As these nets are passive gear that allow turtles to surface to breathe, they provide an excellent method of sampling sea turtles.

Because of the large number of turtles in the PAE Complex and their accessibility from pound nets, an in-water survey was begun in 1995 to monitor trends in sea turtle populations (Epperly et al. 2007). Based on sea turtle captures in pound nets in the PAE Complex sampled from 1995 to 1997 and 2001 to 2003, Epperly et al. (2007) reported an increase in loggerhead catch rates of $13 \%$ of the 1995 catch per unit effort (CPUE) per year; however, they did not detect a trend in catch rates for green or Kemp's ridley turtles. In this paper, we include results from a third sampling period, 2007-2009, to examine long-term trends in catch rates, species composition, and size distribution.

\section{MATERIALS AND METHODS}

We randomly selected pound net fishers every week from the North Carolina Division of Marine Fisheries' registration file. Four observers (1 based on Hatteras Island, 1 on Ocracoke Island, and 2 in Carteret County; Fig. 1) attempted to sample 3 fishing trips each per week, resulting in 12 sampling

trips per week. Although the samplers attempted to complete 12 trips each week of the study, at times this was not possible because either (1) fishers were not fishing due to factors such as adverse weather conditions and crew availability or (2) all fishers were active on the same day/s during a given week and samplers could only complete 1 fishing trip per day. During the first 2 sampling periods (1995-1997 and 2001-2003), surveys lasted 13 wk (from midSeptember to mid-December) (Epperly et al. 2007); however, because of a season closure of the commercial harvest of flounder in internal coastal waters from December 1 to 31 beginning in 2005 (FF-41-2005; www.ncfisheries.net/procs/procs2k5/FF41-2005.htm), the $3^{\text {rd }}$ sampling period (2007-2009) lasted $11 \mathrm{wk}$. Therefore, we restricted data analysis to the 11 comparable weeks among sampling periods. Multiple pound nets are often connected together into a set, and during a fishing trip, we recorded location and registration number of the set and number of pounds per set so that catch rate analyses could be conducted by pound net or set (see Epperly et al. 2007 for a detailed description of this fishery). We also recorded soak time, or length of time since the nets were last fished, so that we could calculate fishing effort. We collected water temperature data at the beginning of each trip using calibrated thermometers and recorded species and 
number of turtles captured. Weekly aerial surveys were flown to count the total number of pounds being fished to calculate the proportion of total fishing effort we were sampling.

Captured turtles were brought onboard and checked for identification tags. If none were found, an Inconel tag was applied to each rear flipper and a $125 \mathrm{kHz}$ passive integrated transponder (PIT) injected into 1 front flipper. We did not apply Inconel tags to turtles with straight carapace length notch to tip (SCLn-t) (Bolten 1999) less than $25 \mathrm{~cm}$. Because of the low probability of losing all 3 tags (Braun McNeill et al. 2013), we were confident in our ability to identify recaptures. We measured SCL to identify life stages captured and to determine if shifts in size distributions were occurring. For each species, we compared each sampling year's mean SCL and size frequency distributions using parametric (ANOVA) and non-parametric (Kolmogorov-Smirnov, KS) statistics, respectively (SAS ${ }^{\circledR}$ Ver. 9.1 NPAR1WAY procedure).

During 2008 and 2009, permit restrictions prevented us from measuring turtles or using conventional (Inconel, PIT) tagging methods, but we were still able to confidently identify recaptures using photo identification (Goodman Hall \& Braun McNeill 2013). We removed all subsequent within-year recaptures when calculating annual number of turtles captured by species; however, we retained all recaptures between years, considering them unique captures. Because of the large number of zeros in the data set, we used the delta-lognormal estimator (Pennington 1983) to estimate the mean and variance of sea turtle CPUE. We assumed set was the independent variable, because sets are fixed in space and randomly selected; however, the number of pounds and soak days differs by set. All mean, variance, and confidence intervals of CPUE estimates were implemented in MATLAB (Ver. R2015b). Our MATLAB implementation consisted of first calculating the mean and variance of the natural logarithm of the non-zero portion of the data set. Using this mean and variance, with counts of the total number of zeros, the total number of non-zero points, and a tolerance value (for precision, see later in this paragraph), we used Eqs. (2) \& (4) from Pennington (1983) (see our MATLAB function deltLog.m in Supplement 1 at www.int-res.com/articles/suppl/n036p315_supp.pdf) to estimate the delta-lognormal mean $(\mathrm{dm})$ and delta-lognormal variance (dv), respectively. Our deltLog function calls another function, G.m (in Supplement 2), which implements Eq. (3) from Pennington (1983). This G function needs a tolerance value, which we set at 21, yielding the maximum precision of 15 significant digits. Finally, assuming the sample was large, we estimated the lower $95 \%$ confidence interval as $\mathrm{dm} / \mathrm{dc}$ and the upper confidence interval as $\mathrm{dm} \times \mathrm{dc}$, where $\mathrm{dc}=\mathrm{e}^{1.96 \times \sqrt{\ln \left(1+\frac{\mathrm{dm}}{\mathrm{dv}^{2}}\right)}}$. Likewise, the coefficient of variation (CV) was estimated in the usual way, as $\mathrm{CV}=\frac{\sqrt[2]{\mathrm{dv}}}{\mathrm{dm}}$. We used linear regression (SAS ${ }^{\circledR}$ Ver. 9.1) to determine if significant changes had occurred in annual mean CPUEs for each species, using a significance level $\alpha=0.05$.

\section{RESULTS}

A majority $(98.5 \%)$ of captured turtles were juveniles (according to adult sizes reported by the respective species recovery plans), re-emphasizing the importance of this habitat to juvenile sea turtles. As stated in 'Materials and methods', we restricted all analyses to Weeks 1 to 11 of all 3 sampling periods (1995-1997, 2001-2003, and 2007-2009). Although fishing effort (sets and pound nets counted) within each sampling period usually peaked during Weeks 7 to 10 , the number of sets being fished noticeably declined among sampling periods (Fig. 2). For example, from 1995 to 1997, 7045 sets were being fished; however, from 2007 to 2009, that number had dropped to 2579 sets. As a result of this decline in fishing effort, the number of sets we sampled in 2007-2009 ( $\mathrm{n}=804)$ likewise decreased from that sampled in 1995-1997 ( $\mathrm{n}=1043)$. Despite this decrease in total sets sampled, however, the total

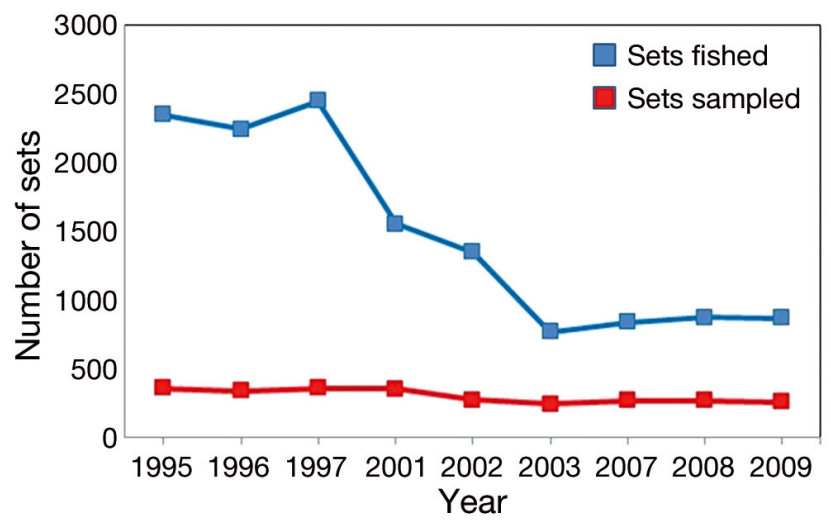

Fig. 2. Weekly fishing effort (sets counted) and sampling effort (sets sampled) in the North Carolina autumn pound net fishery south of Oregon Inlet, September to November 1995-1997, 2001-2003, and 2007-2009. Sets were counted during weekly aerial surveys of the Pamlico-Albemarle Estuarine Complex. Week 1 begins in mid-September (September 14-17), Week 11 ends at the end of November 
number of turtles captured in 2007-2009 $(\mathrm{n}=946)$ nearly doubled that captured in 1995-1997 $(\mathrm{n}=447)$ (Table 1) and comprised $44 \%$ of the overall turtle catch $(1995-2009 ; n=2150)$. We also recorded dead turtles: 3 loggerheads, 31 green, and 1 Kemp's ridley; however, these turtles were not included in the analyses. After removal of within-year recaptures ( $6.4 \%$ of total captures), we used the unique 1265

Table 1. Total number of loggerhead, green, and Kemp's ridley sea turtles captured, number of recaptures, estimated total unique individuals (total captured minus recaptures), and species composition in the North Carolina pound net fishery, September to November 1995-2003 (Epperly et al. 2007) and 2007-2009; recaptures between years $(\mathrm{n}=15)$ were retained. Estimated total unique individuals from 1995 to 2007 include 36 loggerhead and 1 green turtle that escaped before it could be determined if they had tags; estimated total unique individuals from 2008 to 2009, when photo identification was used, include 25 loggerhead, 11 green, and $10 \mathrm{Kemp}$ 's ridley turtles for which image quality was poor or no image was available by which to identify them. Turtles encountered dead in the net are shown in parentheses

\begin{tabular}{|c|c|c|c|c|}
\hline Year & $\begin{array}{c}\text { Total } \\
\text { captured }\end{array}$ & $\begin{array}{l}\text { Recaptures } \\
\text { within year }\end{array}$ & $\begin{array}{c}\text { Estimated } \\
\text { total } \\
\text { unique } \\
\text { individuals }\end{array}$ & $\begin{array}{c}\text { Species } \\
\text { composition } \\
\text { each sampling } \\
\text { period }(\%)\end{array}$ \\
\hline \multicolumn{5}{|c|}{ Caretta caretta } \\
\hline 1995 & 99 & 7 & 92 & \\
\hline 1996 & 87 & 4 & 83 & 73 \\
\hline 1997 & 147 (1) & 2 & 145 & \\
\hline 2001 & 244 & 30 & 214 & \\
\hline 2002 & 201 & 16 & 185 & 73 \\
\hline 2003 & $133(1)$ & 10 & 123 & \\
\hline 2007 & 82 & 2 & 80 & \\
\hline 2008 & $182(1)$ & 18 & 164 & 48 \\
\hline 2009 & 203 & 24 & 179 & \\
\hline Total & 1378 & 113 & 1265 & \\
\hline \multicolumn{5}{|c|}{ Chelonia mydas } \\
\hline 1995 & 41 & 1 & 40 & \\
\hline 1996 & $30(3)$ & 0 & 30 & 24 \\
\hline 1997 & $28(3)$ & 1 & 27 & \\
\hline 2001 & $61(4)$ & 5 & 56 & \\
\hline 2002 & $40(4)$ & 0 & 40 & 19 \\
\hline 2003 & $25(2)$ & 0 & 25 & \\
\hline 2007 & $143(8)$ & 2 & 141 & \\
\hline 2008 & $104(6)$ & 8 & 96 & 43 \\
\hline 2009 & $151(1)$ & 4 & 147 & \\
\hline Total & 623 & 21 & 602 & \\
\hline \multicolumn{5}{|c|}{ Lepidochelys kempii } \\
\hline 1995 & 1 & 0 & 1 & \\
\hline 1996 & 4 & 1 & 3 & 3 \\
\hline 1997 & 10 & 0 & 10 & \\
\hline 2001 & $28(1)$ & 1 & 29 & \\
\hline 2002 & 18 & 0 & 18 & 8 \\
\hline 2003 & 7 & 0 & 8 & \\
\hline 2007 & 9 & 0 & 9 & \\
\hline 2008 & 31 & 1 & 30 & 9 \\
\hline 2009 & 41 & 0 & 41 & \\
\hline Total & 149 & 3 & 146 & \\
\hline
\end{tabular}

loggerhead, 602 green, and 146 Kemp's ridley captures (Table 1) for all subsequent analyses.

Mean CPUEs (captures per set per day) by year for loggerhead turtles ranged from $0.015(95 \% \mathrm{CI}=$ $0.009-0.025)$ in 1995 to $0.085(95 \% \mathrm{CI}=0.057-0.126)$ in 2009 (Fig. 3A), a $467 \%$ increase. The CV for the annual CPUE estimates ranged from 0.19 (2001) to 0.28 (1995). During the first 2 sampling periods (1995-1997 and 2001-2003), mean annual CPUEs increased significantly $($ CPUE $=$ $-8.68+0.0044 \times$ year, $\left.R^{2}=0.99, p<0.001\right)$ (Epperly et al. (2007). Using only Weeks 1 to 11 and including the 2007-2009 data, mean CPUE continued to display an increasing trend (CPUE $=-5.72+0.0029 \times$ year, $\mathrm{R}^{2}=0.51, \mathrm{p}=0.031$ ) from 1995 to 2009 ; however, this may have been due to the substantial increase in CPUE for 2009, as CPUE had declined (2007) or remained unchanged (2008) compared to previous years (Fig. 3A). Mean CPUEs for green turtles ranged from $0.0025(95 \% \mathrm{CI}=0.0013-$ $0.0047)$ in 1997 to 0.085 (95\% CI $=0.053-$ 0.138) in 2007 (Fig. 3B), a $4250 \%$ increase; CVs ranged from 0.20 (2008) to 0.46 (2003). Although Epperly et al. (2007) did not detect a trend in mean CPUE for green turtles, using only Weeks 1 to 11 and including the 2007-2009 data resulted in an increasing trend in mean green turtle CPUE (CPUE $=-7.64+0.0038 \times$ year, $\left.R^{2}=0.54, p=0.024\right)$ from 1995 to 2009 (Fig. 3B). Mean CPUE for Kemp's ridley turtles ranged from essentially zero $\left(1.19 \times 10^{-5} ; 95 \% \mathrm{CI}=2.32 \times\right.$ $10^{-6}-6.07 \times 10^{-5}$ ) in 1995 (Epperly et al. $2007)$ to $0.010(95 \% \mathrm{CI}=0.005-0.017)$ in 2009 (Fig. 3C), and CVs ranged from 0.31 (2009) to 0.66 (1996). We likewise detected an increasing trend in annual CPUEs $\left(\right.$ CPUE $=-0.93+0.0005 \times$ year, $R^{2}=0.61, p=$ 0.013 ) for Kemp's ridleys from 1995 to 2009 (Fig. 3C).

In addition to the increase in capture rates for all 3 sea turtle species, we also detected a noticeable shift in species composition over the entire sampling period. During the latter part of the sampling period (20072009), the percentage of loggerheads decreased while that of greens and Kemp's ridleys increased (Table 1).

Loggerhead turtles ranged in size from 41.4 to $102.5 \mathrm{~cm} \mathrm{SCL}$, with a median of $62.9 \mathrm{~cm}$ and a mean of $62.7 \mathrm{~cm}(\mathrm{SD}=7.68$, 

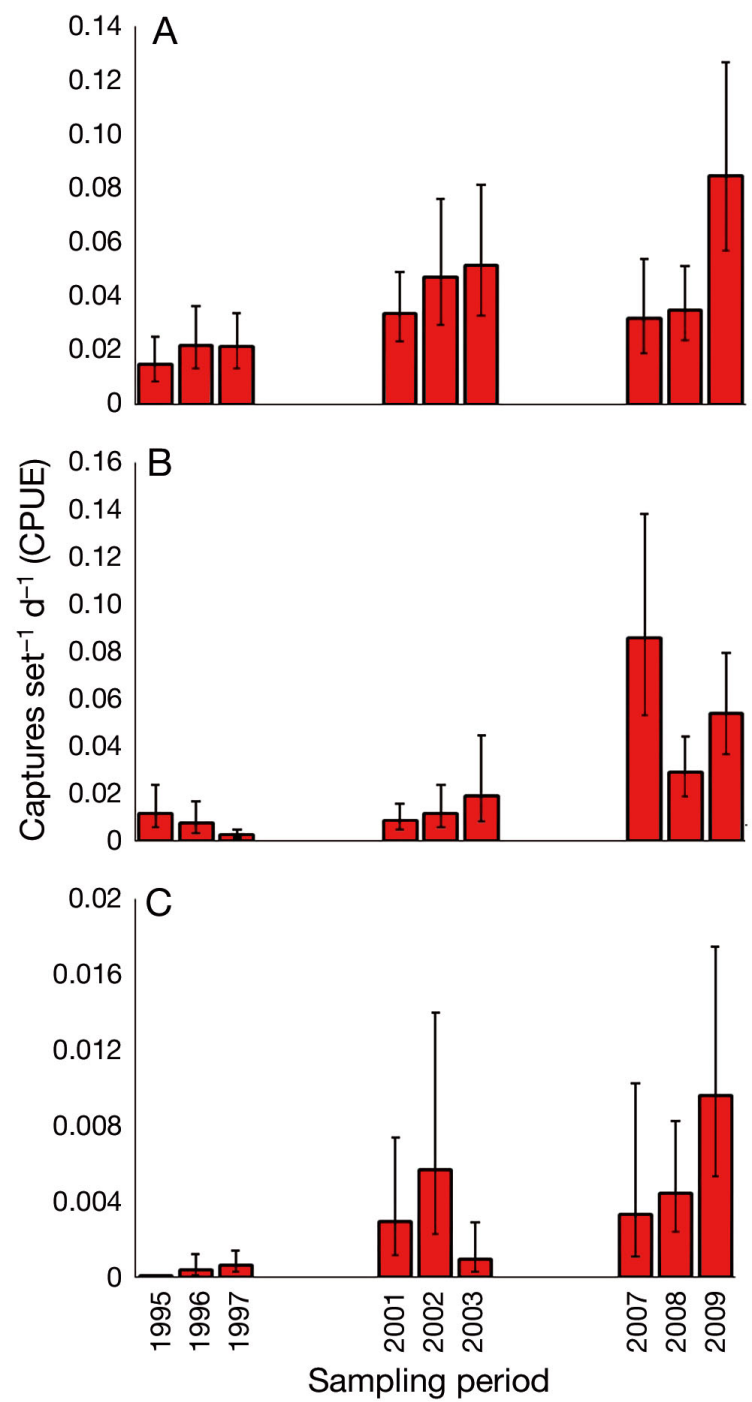

Fig. 3. Annual mean catch per unit effort (CPUE) by year for (A) loggerhead, (B) green, and (C) Kemp's ridley sea turtles in eastern Pamlico, Core, and Back sounds, NC, September to November 1995-1997, 2001-2003, and 2007-2009. Bars indicate $95 \%$ confidence limits. Note that the ordinate scales differ by species

$\mathrm{n}=867$ ) (Fig. 4). Mean size and size distribution varied significantly among years (ANOVA, $F=14.6148$, $\mathrm{p}<0.0001, \mathrm{df}=6 ; \mathrm{KS}=0.140767, \mathrm{p}<0.0001, \mathrm{n}=867$ ). As stated in 'Materials and methods', permit restrictions only allowed us to include size data for 2007; even so, loggerheads captured during 2007 continued demonstrating the significant size shift revealed in Epperly et al. (2007). At the beginning of the study, the predominant size class was 55 to $59 \mathrm{~cm}$, while this predominance shifted to $60-65 \mathrm{~cm}$ during $2002-$ 2003. In 2007, predominant size classes were 60 to 65 and 65 to $70 \mathrm{~cm}$ (Fig. 4). Green turtles ranged in size from 20.6 to $79.6 \mathrm{~cm} \mathrm{SCL}$, with a median of $30.0 \mathrm{~cm}$

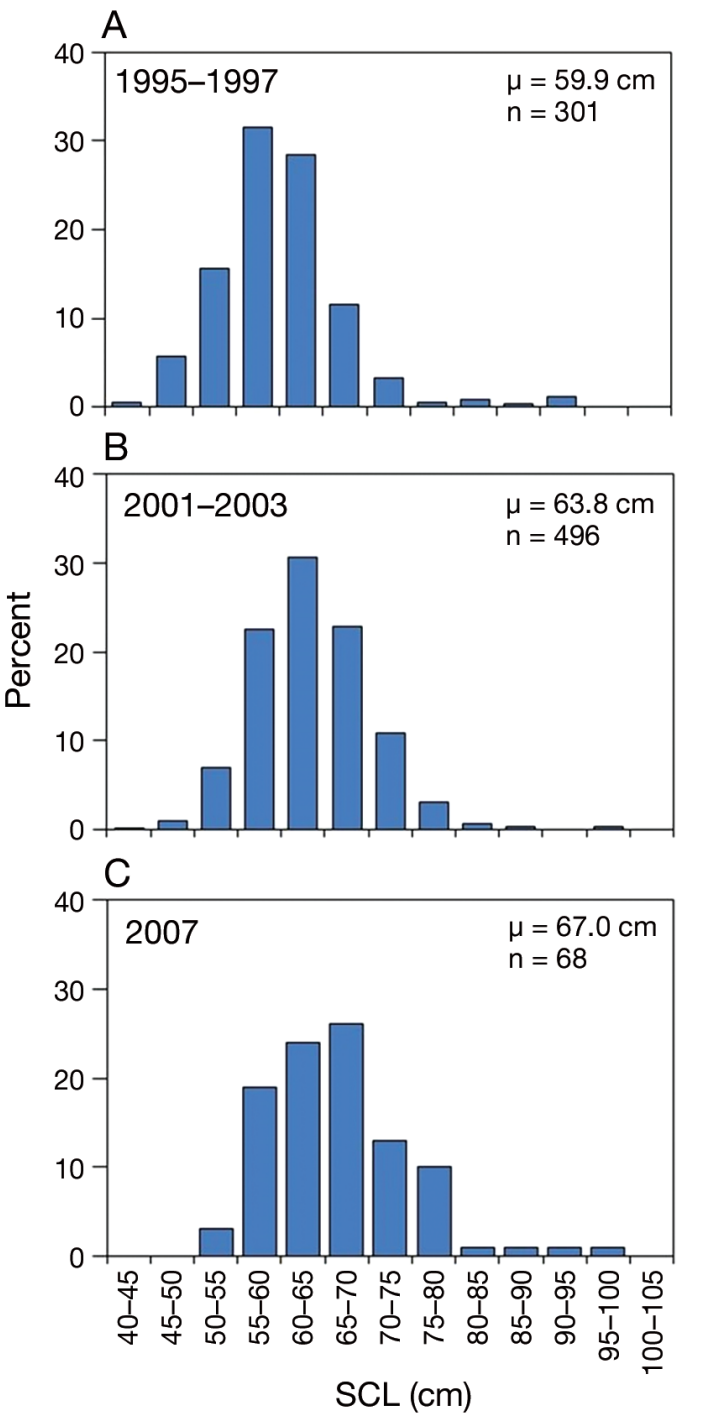

Fig. 4. Annual size frequency distributions of loggerhead sea turtles captured in eastern Pamlico, Core, and Back sounds, NC. (A) 1995-1997, (B) 2001-2003, and (C) 2007. During 2008 and 2009, permit restrictions prevented us from handling the turtles. SCL: straight carapace length; $\mu$ : mean. Individuals at the junction of 2 size increments were placed in the larger increment

and a mean of $32.2 \mathrm{~cm}(\mathrm{SD}=9.28, \mathrm{n}=336$ ) (Fig. 5). Mean size and size distribution of green turtles varied significantly among years (ANOVA, $F=3.1715$, $\mathrm{p}<0.005, \mathrm{df}=6 ; \mathrm{KS}=0.190289, \mathrm{p}<0.0001, \mathrm{n}=336$ ), and there was a shift toward smaller turtles in 2007. During the first 2 sampling periods, the predominant size class was 30 to $35 \mathrm{~cm}$, with the exception of 1996 when the predominant size class was 25 to $30 \mathrm{~cm}$. However, during 2007, the predominant size class shifted to $25-30 \mathrm{~cm}$. Kemp's ridley turtles ranged in size from 25.6 to $56.3 \mathrm{~cm} \mathrm{SCL}$, with a median of $41.8 \mathrm{~cm}$ and a mean of $41.9 \mathrm{~cm}(\mathrm{SD}=7.47, \mathrm{n}=72)$ (Fig. 6). Mean size and size distribution of Kemp's did 


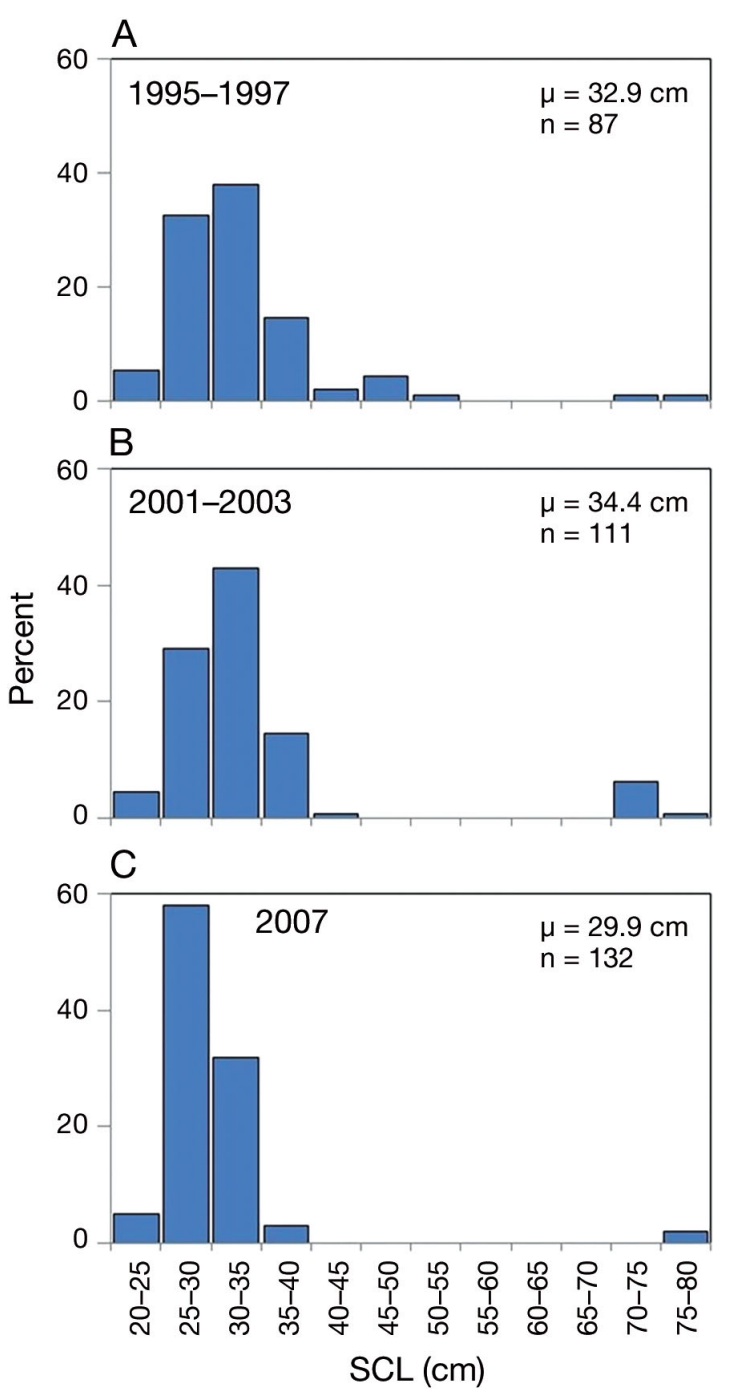

Fig. 5. Annual size frequency distributions of green sea turtles captured in eastern Pamlico, Core, and Back sounds, NC. (A) 1995-1997, (B) 2001-2003, and (C) 2007. During 2008 and 2009, permit restrictions prevented us from handling the turtles. SCL: straight carapace length; $\mu$ : mean. Individuals at the junction of 2 size increments were placed in the larger increment

not vary significantly among years (ANOVA, $F=$ 2.0813, $\mathrm{p}<0.1, \mathrm{df}=4 ; \mathrm{KS}=0.175059, \mathrm{p}<0.1, \mathrm{n}=73$ ), nor was there any significant shift in size class among the 3 periods, likely due to the small sample size.

\section{DISCUSSION}

Trends in sea turtle populations derived from capture rates of fishery-dependent sampling are essential for sea turtle population assessments (Epperly et al. 2007, Arendt et al. 2012, Silva et al. 2017). In this study, we identified obvious increases in capture
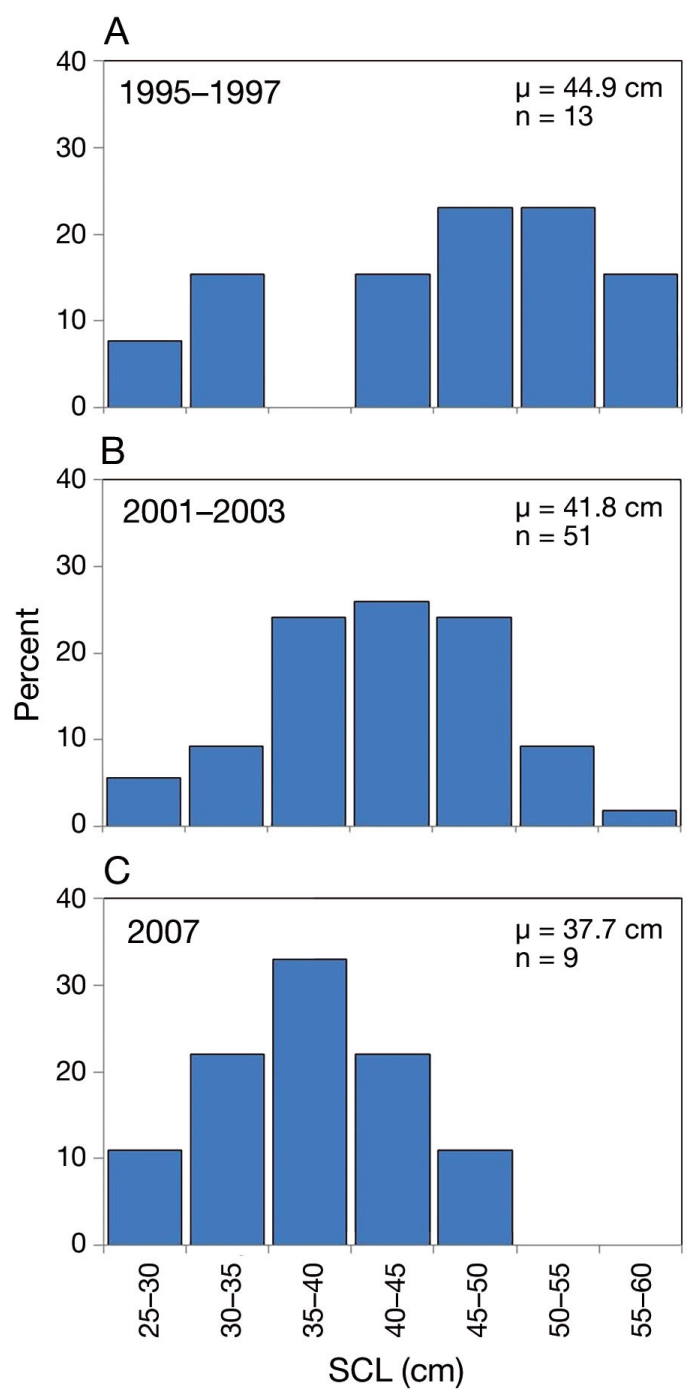

Fig. 6. Annual size frequency distributions of Kemp's ridley sea turtles captured in eastern Pamlico, Core, and Back sounds, NC. (A) 1995-1997), (B) 2001-2003, and (C) 2007. During 2008 and 2009, permit restrictions prevented us from handling the turtles. SCL: straight carapace length; $\mu$ : mean. Individuals at the junction of 2 size increments were placed in the larger increment

rates for all 3 species during a 15 yr span (19952009). To infer that population abundance is likewise increasing for these 3 species, we must operate under the assumption that capture rates are proportional to abundance. Numerous factors can affect the relationship of capture rates and abundance, including variability of fishing operations, gear efficiency, species targeting, and non-random sampling effort (Walters 2003). From 1995 to 2009, we observed no changes in fishing gear or fishing methodology; therefore, variable fishing operations and gear efficiency were not factors affecting capture rates. Additionally, the fishery was not targeting sea turtles; consequently, fish- 
ing effort did not vary with turtle captures. However, because the probability of capturing a sea turtle likely was associated with the number of nets in the water, catchability could be related to effort. Likewise, although fishers were randomly selected, and turtles were caught passively, the nets were not placed randomly in the sounds but rather where flounder catches were thought to be greatest; thus, there might be a co-occurrence of sea turtles and flounder.

Most (98.5\%) of the turtles captured were juveniles and represent a certain proportion of the overall population. Thus, we are also making the assumption that increasing capture rates of juvenile sea turtles in North Carolina sounds represented a similar increasing trend in other western Atlantic sea turtle populations and compare our trends to population trends of other abundance studies. Our loggerhead capture rates increased significantly throughout this $15 \mathrm{yr}$ period, indicating a potential increase in loggerhead abundance. In a similar long-term study of sea turtles in Florida estuarine waters, Ehrhart et al. (2007) documented increases in loggerhead capture rates during the 24 yr study, though with no apparent trend. However, they did observe that a significant increase occurred during the last $4 \mathrm{yr}$ of the study but cautioned that these were not enough data to establish a trend. Similarly, in a long-term trawling study in coastal waters from Florida to South Carolina, Arendt et al. (2012) recorded stable catch rates of loggerheads from 2000 to 2011 but also were not able to detect a significant trend. Finally, an increase in captures of loggerheads ( $11 \% \mathrm{yr}^{-1}$ from 1988 to 2005) within the St. Lucie Power Plant's intake canal (on Hutchinson Island, Florida) was noted in an assessment of the loggerhead population in the western North Atlantic Ocean (Turtle Expert Working Group 2009).

Despite these encouraging trends in loggerhead abundance derived from in-water studies, there is concern about notable decreases in nests of all western North Atlantic loggerhead subpopulations during this same time period (Turtle Expert Working Group 2009). In particular, the peninsular Florida subpopulation, which contains $80 \%$ of all nesting in the western North Atlantic, has seen a 29 to $37 \%$ decrease in annual number of nests from 1989 to 2006 (Witherington et al. 2009). While several hypotheses have been proposed as to the reasons for this decline, no definitive explanation could be derived; however, this decline in nests and consequential decline in hatchlings will likely result in depressed recruitment during the coming decades (Turtle Expert Working Group 2009)
The inclusion of 2007-2009 data documented a significant increase in capture rates of juvenile green turtles from 1995 to 2009 in North Carolina estuarine waters. Increased captures of green turtles were also recorded in Florida, at the Indian River Lagoon site from 1982 to 2006 (Ehrhart et al. 2007) and at the St. Lucie Power Plant site from 1977 to 2002 (Witherington et al. 2006). The majority of turtles captured within this North Carolina foraging aggregation are post pelagic and derive from rookeries in the USA and Mexico (Bass et al. 2006). Thus, when considering an average oceanic stage duration of $3 \mathrm{yr}$ (Goshe et al. 2010), this leads to a conclusion that our increase in juvenile green sea turtle captures is likely a reflection of the decades-long exponential increase in green turtle nesting rookeries (Chaloupka et al. 2008, Seminoff et al. 2015).

Conversely, in a capture-mark-recapture study of 2 green turtle foraging grounds in the Bahamas, Bjorndal et al. (2005) did not detect a significant change in abundance in Union Creek from 1978 to 2001; however, the foraging population in Conception Creek increased significantly from 1979 to 1985, decreased from 1985 to 1994, and remained stable from 1994 to 2001. The authors attributed these changes in abundance to changes in immigration rather than survival or emigration. However, the changes in abundance they documented on the foraging grounds did not relate to the significant increasing nesting trends for the source rookery at Tortuguero, Costa Rica. Consequently, Bjorndal et al. (2005) highlighted the need for extensive (aerial or vessel) surveys in conjunction with intensive (capture-mark-recapture) surveys for monitoring population-wide trends of long-lived species, such as the green sea turtle.

Epperly et al. (2007) documented an increase in Kemp's ridley captures during 2001 and 2002, but because of so few captures in 2003, no conclusive trend in Kemp's ridley abundance could be determined. In contrast, we recorded an increase in capture rates during 2008 and 2009, suggesting a possible increase in population abundance. Through protective conservation measures (prohibiting egg harvest in the 1970s and reducing incidental takes of sea turtles in trawlers in the 1990s), Kemp's ridleys experienced exponential growth in number of nests through 2009 (NMFS, USFWS 2015). As age of sexual maturity is estimated to be $12 \mathrm{yr}$ (Avens et al. 2017), the increase in capture rates of Kemp's ridleys we observed (all of which are juveniles) may be a result of the exponential growth of the Kemp's ridley nesting population. However, in 2010, concurrent with the Deepwater Horizon oil spill, the Kemp's ridley 
nesting population experienced a decrease of $30 \%$ compared to the previous year, and because of an additional decrease in 2014, there are concerns about population recovery (NMFS, USFWS 2015). It would be instructive to see if the juvenile population in our study site followed this trend, with capture rates declining in 2017, as those turtles which had hatched since the 2014 nesting season began to recruit to nearshore waters. Interestingly, since the decrease in 2014, encouraging increases in number of nests have occurred in both Texas and Mexico. In fact, nest numbers increased $90 \%$ in Texas and $30 \%$ in Mexico during the 2017 season (D. Shaver, US National Park Service, pers. comm.), suggesting that our increase in capture rates of the juvenile population may be reflected in the adult population with a corresponding increase in nesting numbers.

Notably, we found a distinct shift in species composition during the $15 \mathrm{yr}$ span. From 1995 to 1997, loggerheads were the dominant species, comprising $75 \%$ of our sea turtle foraging population. However, from 2007 to 2009, green turtle captures had increased so that the percentage of greens (42\%) was comparable to loggerheads (49\%). North Carolina stranding data showed a similar pattern (M. Godfrey, North Carolina Wildlife Resources, pers. comm.) (www.seaturtle.org/strand/summary). In 1998, when stranding data collection became systematic, loggerheads made up a greater percentage $(68 \%)$ of stranding totals and ranged from 65 to $80 \%$ through 2006. However, in 2007, the number of stranded green turtles $(n=141)$ nearly doubled that of the annual average (mean, $\mu=73,1998-2006$ ), and, except for 2011 and 2012, the percentage of stranded green turtles has surpassed that of loggerheads every year since. The percentage of stranded Kemp's ridleys has also increased since 1998 (range: 9-34\%, $\mu=18 \%$ ). Both stranding and in-water capture data reveal an increased representation of green and Kemp's ridley sea turtles in the waters of coastal North Carolina.

Although we were able to collect only 1 more year of SCL data (2007), the shift toward an increase in larger-sized loggerheads as noted in Epperly et al. (2007) was again apparent, with $>75 \%$ of loggerheads larger than $60 \mathrm{~cm}$ in 2007 compared to 40\% in 1995. Loggerheads in Florida's estuarine waters (Ehrhart et al. 2007) and coastal waters from Florida to South Carolina (Arendt et al. 2012) demonstrated similar shifts in size. Ehrhart et al. (2007) documented an increase in the median size of loggerheads from 1982 to 1989 and from 1998 to 2005; however, from 1990 to 1997, the median size declined by $4 \mathrm{~cm}$. Arendt et al. (2012), in a study from 2000 to 2011, described this shift in size as an increase in frequency of a larger $(75.1-80 \mathrm{~cm})$ size class, noting that loggerhead captures of this size represented only $2 \%$ of the population in 2000 but had increased nearly 10 times that much in 2011. Their explanation for the increased frequency of this size class included an assumption of $11 \mathrm{yr}$ (Conant et al. 2009) and $50 \mathrm{~cm}$ min SCL (notch to notch) (Bjorndal et al. 2003) as average age and size at recruitment, respectively. By adding an additional $17.4 \mathrm{yr}$ to reach $80 \mathrm{~cm}$ (Braun-McNeill et al. 2008), they theorized that loggerheads in the $75.1-80 \mathrm{~cm}$ size class captured in 2011 had likely hatched in the mid- to late 1980 s, a time of increased nest counts (Witherington et al. 2009). Thus, the shift toward an increase in larger-sized loggerheads may represent the growth of a dominant cohort in the population.

Although a shift in size of Kemp's ridleys could not be detected (likely because of a small sample size), mean size and size distribution of green turtles varied significantly among years, and there was a shift toward smaller turtles in 2007. This increase in the number of smaller turtles likewise reflects the decades-long increase in green turtle nesting as post hatchlings move into the neritic environment.

Because of the complex life cycle of sea turtles, conducting accurate assessments of sea turtle populations is difficult, requiring long-term studies that include multiple life stages (Chaloupka \& Limpus 2001, Heppell et al. 2003, National Research Council 2010). However, high cost and logistical difficulty make these all-encompassing studies challenging to execute; consequently, most population studies are focused on a single life stage in a particular location. Because assessing sea turtle populations from just a single site cannot accurately reveal population trends, establishing a network of in-water study sites within both neritic and oceanic habitats to monitor in-water population abundance and trends is essential (NMFS, USFWS 2008), and data can then be extrapolated to determine how populations will react to perturbations (Heppell et al. 2003).

Our in-water research focused on the neritic juvenile life stage of 3 species of sea turtles (loggerhead, green, and Kemp's ridley) and detected a discernible increase in the capture rate of all 3 species from 1995 to 2009. Despite this encouraging increase, caution should be exercised when interpreting these data. Catch rates displayed substantial inter-annual variability, demonstrating the highly variable nature of ratio estimators when applied to relatively rare event data. In addition, total effort in the pound net fishery declined during the study, potentially reducing the 
relative number of available traps for turtles and changing capture probabilities. Moreover, given the delayed sexual maturity of sea turtles, $15 \mathrm{yr}$ likely does not capture definitive trends in sea turtle populations; thus, in-water research should continue for several decades so that actual trends can be detected. Nevertheless, this sampling enabled us to detect a statistically significant increase in capture rates for all 3 sea turtle species, along with obvious changes in species composition of the foraging sea turtle community in the PAE Complex. In addition, our study was key in acquiring a better understanding of sea turtle population dynamics in this region. We recommend continuing in-water research at several sites along the coast to acquire a better understanding of sea turtle population dynamics in this region, so that more effective recovery and management plans for these species can be implemented.

Acknowledgements. Special thanks go to Sheryan P. Epperly for her extensive contributions at the beginning of this long-term study and for her continued support and encouragement. We are indebted to the many samplers who collected sea turtle data as well as all of the commercial pound net fishers who participated in the study. We are grateful to Tradewind Aviation for providing aerial census data. We appreciate Kate Siegfried, Aleta Hohn, Matthew Godfrey, Alex Chester, and anonymous reviewers for insightful comments on the manuscript. This research was conducted under the authority of US Endangered Species Act Section 10(a)(1)(A) scientific research permits from the US Fish and Wildlife Service (\#TE676379) and the National Marine Fisheries Service (NMFS) (\#1260). NMFS does not approve, recommend, or endorse any proprietary product or material mentioned in this article.

\section{LITERATURE CITED}

Arendt MD, Schwenter JA, Boynton J, Segars AL, Byrd JI, Whitaker JD, Parker L (2012) Temporal trends (20002011) and influences on fishery-independent catch rates for loggerhead sea turtles (Caretta caretta) at an important coastal foraging region in the southeastern United States. Fish Bull 110:470-483

Avens L, Goshe LR, Coggins L, Shaver DJ, Higgins B, Landry AM Jr, Bailey R (2017) Variability in age and size at maturation, reproductive longevity, and long-term growth dynamics for Kemp's ridley sea turtles in the Gulf of Mexico. PLOS ONE 12:e0173999

Bass AL, Epperly SP, Braun-McNeill J (2006) Green turtle (Chelonia mydas) foraging and nesting aggregations in the Caribbean and Atlantic: impact of currents and behavior on dispersal. J Hered 97:346-354

Bjorndal KA, Bolten AB, Dellinger T, Delgado C, Martins HR (2003) Compensatory growth in oceanic loggerhead sea turtles: response to a stochastic environment. Environ Ecol 84:1237-1249

Bjorndal KA, Bolten AB, Chaloupka MY (2005) Evaluating trends in the abundance of immature green turtles, Chelonia mydas, in the greater Caribbean. Ecol Appl 15: 304-314

Bolten AB (1999) Techniques for measuring sea turtles. In: Eckert KL, Bjorndal KA, Abreu-Grobois FA, Donnelly M (eds) Research and management techniques for the conservation of sea turtles. IUCN/SSC Marine Turtle Specialist Group, Washington, DC, p 110-114

Braun-McNeill J, Epperly SP, Avens L, Snover ML, Taylor JT (2008) Growth rates of loggerhead sea turtles (Caretta caretta) from the western North Atlantic. Herpetol Conserv Biol 3:273-281

Braun McNeill J, Schueller AM, Avens L, Hall AG, Goshe LR, Epperly SP (2013) Estimates of tag loss for loggerhead sea turtles (Caretta caretta) in the western North Atlantic. Herpetol Rev 44:221-226

* Broderick AC, Godley BJ, Hays GC (2001) Trophic status drives interannual variability in nesting numbers of marine turtles. Proc R Soc B 268:1481-1487

* Broderick AC, Frauenstein R, Glen F, Hays GC and others (2006) Are green turtles globally endangered? Glob Ecol Biogeogr 15:21-26

Butler RW, Nelson WA, Henwood TA (1987) A trawl survey method for estimating loggerhead turtle, Caretta caretta, abundance in five eastern Florida channels and inlets. Fish Bull 85:447-453

Chaloupka MY, Limpus CJ (2001) Trends in the abundance of sea turtles resident in southern Great Barrier Reef waters. Biol Conserv 102:235-249

* Chaloupka M, Bjorndal KA, Balazs GH, Bolten AB and others (2008) Encouraging outlook for recovery of a once severely exploited marine megaherbivore. Glob Ecol Biogeogr 17:297-304

Conant TA, Dutton PH, Eguchi T, Epperly SP and others (2009) Loggerhead sea turtle (Caretta caretta) 2009 status review under the US Endangered Species Act. In: Report of the Loggerhead Biological Review Team to the National Marine Fisheries Service, August 2009

Ehrhart LM, Redfoot WE, Bagley DA (2007) Marine turtles of the central region of the Indian River lagoon system, Florida. Fla Sci 70:415-434

* Epperly SP, Braun J, Veishlow A (1995) Sea turtles in North Carolina waters. Conserv Biol 9:384-394

Epperly SP, Braun-McNeill J, Richards PM (2007) Trends in catch rates of sea turtles in North Carolina, USA. Endang Species Res 3:283-293

Goodman Hall A, Braun McNeill J (2013) Inferring sea turtle recapture rates using photographic identification. Herpetol Rev 44:561-568

Goshe LR, Avens L, Scharf FS, Southwood AL (2010) Estimation of age at maturation and growth of Atlantic green turtles (Chelonia mydas) using skeletochronology. Mar Biol 157:1725-1740

Heppell SS, Snover ML, Crowder LB (2003) Sea turtle population ecology. In: Lutz PL, Musick JA, Wyneken J (eds) The biology of sea turtles, Vol II. CRC Press, Boca Raton, FL, p 275-306

Higgins E, Pearson JC (1928) Examination of the summer fisheries of Pamlico and Core Sounds, NC, with special reference to the destruction of undersized fish and the protection of the gray trout Cynoscion regalis (Block and Schneider), Appendix II. Report of the United States Commissioner of Fisheries for the Fiscal Year 1927 with Appendices. US Dept of Commerce, Bureau of Fisheries, Government Printing Office, Washington DC, p 29-65 
Meylan AB (1995) Estimation of population size in sea turtles. In: Bjorndal KA (ed) Biology and conservation of sea turtles (revised edn). Smithsonian Institution, Washington, DC, p 135-138

National Research Council (2010) Assessment of seaturtle status and trends: integrating demography and abundance. The National Academies Press, Washington, DC

NMFS (National Marine Fisheries Service), USFWS (US Fish and Wildlife Service) (2008) Recovery plan for the Northwest Atlantic population of the loggerhead sea turtle (Caretta caretta), 2nd rev. National Marine Fisheries Service, Silver Spring, MD

NMFS, USFWS (2015) Kemp's ridley sea turtle (Lepidochelys kempii) 5-year review: summary and evaluation, July 2015. https://repository.library.noaa.gov/view/noaa/ 17048

Pennington M (1983) Efficient estimators of abundance, for fish and plankton surveys. Biometrics 39:281-286

Pfaller JB, Bjorndal KA, Chaloupka M, Williams KL, Frick MG, Bolten AB (2013) Accounting for imperfect detection is critical for inferring marine turtle nesting population trends. PLOS ONE 8:e62326

Schroeder BA, Murphy S (1999) Population surveys (ground and aerial) on nesting beaches. In: Eckert KL, Bjorndal

Editorial responsibility: Paolo Casale,

Pisa, Italy
KA, Abreu-Grobois FA, Donnelly M (eds) Research and management techniques for the conservation of sea turtles. IUCN/SSC Marine Turtle Specialist Group, Washington, DC, p 45-55

Seminoff JA, Allen CD, Balazs GH, Dutton PH and others (2015) Status review of the green turtle (Chelonia mydas) under the U.S. Endangered Species Act. NOAA Tech Memo, NOAA-NMFS- SWFSC-539

Silva BMG, Bugoni L, Almeida BADL, Giffoni BB, Alvarenga FS, Brondizio LS, Becker JH (2017) Long-term trends in abundance of green sea turtles (Chelonia mydas) assessed by non-lethal capture rates in a coastal fishery. Ecol Indic 79:254-264

Turtle Expert Working Group (2009) An assessment of the loggerhead turtle population in the western North Atlantic Ocean. NOAA Tech Memo NMFS-SEFSC-575

*Walters C (2003) Folly and fantasy in the analysis of spatial catch rate data. Can J Fish Aquat Sci 60:1433-1436

Witherington B, Bresette M, Herren R (2006) Chelonia mydas-green turtle. In: Meylan PA (ed) Biology and conservation of Florida turtles. Chelonian Res Monogr 3: 90-104

Witherington B, Kubilis P, Brost B, Meylan A (2009) Decreasing annual nest counts in a globally important loggerhead sea turtle population. Ecol Appl 19:30-54

Submitted: October 25, 2017; Accepted: May 27, 2018

Proofs received from author(s): August 13, 2018 